\title{
DIREITO, ÉTICA E GENERIDADE NA OBRA MADURA DE GYÖRGY LUKACS: ACERCA DAS TENSÕES QUE PERMEIAM O COMPLEXO JURÍDICO
}

\author{
Vitor Bartoletti Sartori ${ }^{1}$
}

\begin{abstract}
Resumo
Problematizando o "posto central do dever-ser", tratar-se-á de analisar como que a questão da ética aparece na obra do último Lukács - aquele da Estética e da Ontologia - a partir de uma crítica ao Direito e ao modo pelo qual a universalidade aparece com base nele e na sociedade capitalista, com aquilo que o autor húngaro chamou de "generidade em-si". Analisar-se-á as tensões que aparecem no próprio complexo jurídico, procurando explicitar a estrutura e as contradições delas a partir da análise lukacsiana. Assim, procura-se explicitar a decidida crítica ao Direito presente na obra de Lukács ao mesmo tempo em que esta crítica redunda na valorização da ética pelo autor.
\end{abstract}

Palavras-chave: Lukács; Direito; Ética; Capitalismo.

\section{INTRODUÇÃO}

Neste artigo, pretende-se abordar o modo mediante o qual, a partir da teorização lukacsiana sobre o Direito, emerge a questão da ética na obra madura do autor húngaro. Para tanto, analisar-se--a, a partir daquilo que Chasin chamou de análise imanente (Cf. CHASIN, 2009) passagens centrais sobre o tema, presentes, principalmente, na Ontologia do ser social, obra magna de György Lukács. Procura-se, assim, a partir da análise dos textos lukacsianos sobre o Direito e a ética, explicitar como que, por vezes, questões decisivas à Ontologia obra central na discussão dos problemas do século XX e, no limite, para que se possa discutir seriamente o papel do marxismo no século XXI (Cf. TERTULIAN, 2016) - remetem a críticas à moral e ao Direito, críticas estas as quais são trazidas à tona por György Lukács em sua obra tardia e que podem ser de grande relevo.

A questão, até certo ponto, e somente até certo ponto, já foi destacada, principalmente no que toca a crítica à moral (Cf. SARTORI, 2015 a), à sua caracterização relacionada ao dever (Sollen) (Cf. ANDRADE, 2016) e à especificidade do Direito (Cf. SARTORI, 2010 a). Foi levada em conta também ao se ter em mente as diferentes figuras que a política tem, segundo Lukács, na sociedade civil-burguesa (bürgerliche Gesellschaft)

${ }^{1}$ Professor Adjunto da faculdade de Direito da UFMG. E-mail: vitorbsartori@gmail.com vol.10, nº. 03, Rio de Janeiro, 2017.pp. 1582-1609 
posterior àquilo que chamou de decadência ideológica da burguesia, e que remetem, inclusive, à peculiar concepção de "democracia socialista" do marxista húngaro. ${ }^{2}$ (Cf. SARTORI, 2016 a) Aqui, no entanto, pretendese trazer à tona a temática da ética ao se ter em conta a importância da oposição entre ela e o Direito ao analisar a crítica lukacsiana ao "posto central do dever-ser". (LUKÁCS, 2012, p. 189) Neste sentido, a tarefa que é proposta neste artigo, até o presente momento, não encontra efetivamente precedentes, já que foi destacada como importante por autores como Tertulian (2010) e Netto (2012), mas não foi desenvolvida ainda; os autores mencionados acima somente tangenciaram o tema que tratamos aqui, neste sentido. Também foi criticada por Mészáros (2002), mas, como se demonstrou noutro lugar (Cf. SARTORI, 2016 a), isto se deu de modo apressado. Assim, ao tratar da questão, até certo ponto, está-se em solo inexplorado e, por isso, é necessária uma análise cuidadosa do texto lukcsiano.

Com isso em mente, ao se tratar da obra do marxista húngaro, procura-se, a partir da análise de seu texto, deixar claro que o ele destaca a questão da ética ao explicitar a indissociabilidade entre a esfera jurídica e aquilo que chamou na sua obra tardia (principalmente na Ontologia e na Estética) de generidade em-si (Gattungsmäßigkeit an sich), esta última a qual, por seu turno, opor-se-ia à generidade para-si (Gattungsmäßigkeit für sich). Esta questão, em verdade, ao tratar da ética, como destaca Nicolas Tertulian, vem a ser central na compreensão do pensamento lukacsiano tardio:

A Ontologia, aí compreendidos os Prolegômenos, culmina efetivamente numa teoria do gênero humano - distinguindo entre Gattungsmäßigkeit an sich e Gattungsmäßigkeit für sich (entre generidade em-si e generidade para-si); seria por meio da Ética que pretendia desenvolver essa problemática. (TERTULIAN, 2010, p. 382)

A culminância da principal obra de Lukács, pois, remete a uma tematização do que o autor chamou de "gênero humano". (Cf. VAISMAN, 2007, 2009) E, pretende-se mostrar: com esta temática em mente, é possível averiguar a posição do autor húngaro diante do Direito e da ética, de tal modo a desenvolver com cuidado, sempre a partir da análise imanente do texto lukacsiano, questões essenciais para uma leitura rigorosa da obra do marxista húngaro, obra a qual, até certo ponto, vem sendo vista de modo apressado, seja no que toca suas determinações mais gerais (Cf. FORTES, 2016), seja no que diz respeito ao Direito. (SARTORI, 2015 b, 2015 a)

Vale destacar que, sobre a questão da generidade, a temática é, de certo modo, dúplice: primeiramente, até certo ponto em confluência com certa crítica "anti-humanista" de importantes marxistas do século XX (Cf. ALTHUSSER, 1999, 2002), a temática é desenvolvida por Lukács ao procurar fugir de qualquer hipostasia da noção de homem (Cf. LUKÁCS, 2010), destacando-se a especificidade de cada esfera do ser social ao mesmo tempo em que se procura demonstrar a inter-relação entre elas na conformação do homem enquanto ser social

\footnotetext{
${ }^{2}$ Somente para que não se cale sobre a questão, vale ressaltar que, para Lukács, superando a oposição entre o burgeois e o citoyen, a democracia socialista opera na medida em que: "a tarefa da democracia socialista é penetrar realmente na inteira vida material de todos os homens, desde a cotidianidade até as questões mais decisivas da sociedade; é dar expressão à sua sociabilidade enquanto produto da atividade pessoal de todos os homens." (LUKÁCS, 2008, p. 117)
} 
histórico e objetivo. ${ }^{3}$ Por outro lado, isto se dá justamente na medida em que o autor da Ontologia traz uma defesa decidida da tradição humanista (Cf. LUKÁCS, 1966), o que se dá de modo diametralmente oposto ao que ocorre na tradição althusseriana, mesmo que, é preciso deixar claro, Lukács não tenha debatido com Althusser. (Cf. SARTORI, 2013) Destacamos a questão pelo seguinte: a tradição marxista de crítica ao Direito que é mais forte no Brasil é fortemente inspirada por Pachukanis e por Althusser (Cf. NAVES, 2000 a, 2000 b, 2014) e remete a uma crítica à igualdade jurídica, à ética e à moral (Cf. KASHIURA, 2009, 2014), de tal modo a adotar uma postura fortemente "anti-humanista" (nos termos althusserianos, adotados por muitos marxistas no Brasil) e avessa a qualquer tipo de valorização da ética, que, na esteira de Pachukanis, é tomada, como sinônimo de moral. ${ }^{4}$ (Cf. SARTORI, 2015 b) Aqui, com Lukács, pretende-se trazer à tona uma posição diversa.

Neste peque no texto, mesmo que de modo sumário, pretende-se trazer à tona uma posição contrária à hipostasia de noções decorrentes de abstrações não razoáveis (Cf. CHASIN, 2009), como aquelas presentes, em grande parte, naquilo que Marx, Lukács e Pachukanis chamaram de Direito burguês e, em especial, relacionadas à noção de sujeito de direito. Em geral, elas são também criticadas pela tradição althusseriana de crítica ao Direito. (Cf. PACHUKANIS, 1988; NAVES, 2000 a; KASHIURA, 2009, 2014). No entanto, intentamos trazer à tona uma versão alternativa da crítica ao Direito, aquela presente em György Lukács. Ela se desenvolve de modo confluente com a tradição althusseriana na crítica àquilo que aparece como um conjunto de abstrações não razoáveis que permeiam a esfera jurídica; no entanto, é discordante da crítica althusseriana e pachukaniana em aspectos, por vezes, essenciais, como aqueles relacionados à possibilidade de valorização do campo da ética e daquilo que o húngaro chamou de humanismo. ${ }^{5}$

Deste modo, pretende-se mostrar que, em verdade, a compreensão acerca da própria noção de gênero humano, em Lukács, não deixa de passar pela problemática da ética, sendo preciso compreender os meandros do tema a partir das oposições centrais ao autor húngaro (dentre elas, aquela entre Direito, ética e moral). Se, como destacou acima Tertulian, "por meio da Ética que [Lukács] pretendia desenvolver essa problemática”, tem-se que a própria compreensão da obra lukacsiana - também em oposição a de grandes marxistas como Althusser - passa por uma análise cuidadosa do modo pelo qual questões decisivas aos trabalhos maduros do marxista húngaro, por vezes, remetem a sua inconclusa obra sobre a ética, obra esta sobre a qual se têm somente fragmentários apontamentos, e que só recentemente foram publicadas no Brasil. (Cf. LUKÁCS, 2015) Deste modo, aqui, a partir da leitura imanente da obra lukacsiana, procura-se adentrar nesta questão trazendo à tona a relação entre a

\footnotetext{
${ }^{3}$ Embora, em essência, seja impossível aproximar Althusser e Lukács, alguns trouxeram certas confluências entre os autores sobre o que mencionamos acima. Cf. TERTULIAN, 2016.

${ }^{4}$ Para Pachukanis, "a moral, o Estado e o Direito são formas da sociedade burguesa." (PACHUKANIS, 1988, p. 137) Complementa ainda o autor dizendo que "a ética kantiana é a típica da sociedade de produção mercantil, mas, igualmente, é a mais pura e acabada da ética em geral.” (PACHUKANIS, 1988, p. 131)
} 
universalidade do Direito, a crítica à generidade que apoia esta universalidade e o modo pelo qual a questão da ética aparece como central a Lukács ao se criticar o mencionado "posto central do dever-ser" e ao remeter a uma questão decisiva a qualquer marxista, aquela, já trazida por Lênin, a do "que fazer?" 6 Deste modo, pode-se começar com a análise imanente de algumas passagens lukacsianas centrais sobre o Direito, mostrando como que elas remetem à questão da ética. A partir disso, procura-se deixar claro o modo pelo qual se conforma a esfera ética diante da peculiar universalidade que marca o complexo jurídico.

\section{DO DIREITO À ÉTICA}

Ao tratar do Direito em sua Ontologia, Lukács procura trazer à tona a especificidade de cada esfera do ser social na medida mesma em que mostra a interdependência entre elas. (Cf. SARTORI, 2010 a) Com isso, correlaciona a reprodução social com o modo pelo qual a esfera jurídica opera; também consegue apontar, por meio de uma análise da reprodução social bastante cuidadosa (Cf. ANDRADE, 2016), tensões presentes no próprio campo do Direito, tensões estas as quais, segundo o autor, não poderiam ter uma solução adequada, de modo algum, no próprio campo jurídico (Cf. SARTORI, 2014), ao mesmo tempo em que este campo não poderia ser deixado de lado, já que exerce uma importante função no ser social justamente por meio de suas ambiguidades. Ao tratar deste aspecto, relacionando a noção de justiça com o funcionamento do Direito positivo, aponta o autor algo importante para o tema, que tem como ponto culminante a tematização sobre a ética:

O tempo de trabalho socialmente necessário enquanto princípio de regulação surge independentemente das representações e da vontade dos homens. Ele é um produto da sumarização efetuada espontaneamente pela sociedade a partir das consequências causais dos pores teleológicos no trabalho. Porém, no sistema jurídico, esses princípios de regulação constituem resultados de um pôr consciente, que enquanto pôr deve determinar as factualidades. Por isso, as reações sociais a ele também acabam sendo necessariamente de outra qualidade. Por essa razão, é facilmente compreensível que a crítica popular e também a literária à injustiça no direito aplicado de modo consequente se concentre nessa discrepância na subsunção do caso singular. Ditados como "summum ius summa iniuria" [o direito excessivo gera a suprema injustiça], composições poéticas como o processo de Shylock, inclusive em suas variantes novelísticas mais antigas, apontam sem exceção para tal ambiente desfavorável à imposição formalmente consequente da lei. Nisso está contido um problema social real. Anteriormente já apontamos para o fato de que nenhum direito pode subsistir se

\footnotetext{
${ }^{5}$ Para uma análise das possibilidades abertas pela vertente althusseriana de crítica ao Direito, Cf. SARTORI, 2015 c; para uma análise da abrangência e limitações da obra pachukaniana, cf. SARTORI, 2015 d.

${ }^{6}$ A questão pode ser interessante também ao passo que, segundo Tertulian, ela figura como um elo importante na crítica àquilo que manchou o marxismo por muito tempo, o stalinismo: "a última grande obra de Lukács Zur Ontologie des gesellschaftlichen Seinsé inspirada pela convicção de que uma regeneração da práxis socialista passa inevitavelmente pela ruptura com o marxismo imobilizado, que havia garantido por seu necessitarismo e por seu "economicismo", tanto o oportunismo da socialdemocracia anterior à primeira guerra mundial, quanto, sobre um outro plano, o stalinismo. Lukács aí propõe restituir à política, ao Direito, à moralidade, a ética o lugar que lhes corresponde na topografia da sociedade, demonstrando que a densidade e a complexidade do tecido social excluem toda codificação a partir de normas abstratas. Gigantesca empreitada histórica de regulação autoritária da vida social, o stalinismo não é uma encarnação do marxismo, mas sua perversão teórica e prática.” (TERTULIAN, 2007 b, p. 39)
} 
não puder ser efetivado mediante a coerção, mas que para que o seu funcionamento se dê com o mínimo de fricção é preciso que haja certa consonância entre seus vereditos na opinião pública. Extrapola os limites deste trabalho verificar quais os esforços reais feitos de tempos em tempos para superar ideologicamente essa discrepância social. Será tarefa da Ética mostrar como a moral nasce essencialmente visando a superação desse abismo que às vezes parece fatal, visando reconciliar no terreno da interioridade aquilo que de modo geral é sentido como injustiça. (LUKÁCS, 2013, p. 242)

Lukács começa o parágrafo trazendo algo de grande relevo para uma abordagem materialista: o fato segundo o qual, por vezes, o processo social passa às costas do sujeito - "independentemente das representações e da vontade dos homens", para que se use a dicção da passagem acima, tem-se a efetividade (Wirklichkeit) de processos que decorrem também da atividade destes. Mesmo que a atividade humana seja um elo cada vez mais necessário à conformação da realidade efetiva, ela perpassa certa espontaneidade que, em especial na sociedade capitalista (Cf. LUKÁCS, 2013; SARTORI, 2012), aparece como uma espécie de segunda natureza e de condição humana. ${ }^{7}$ Deste modo, por vezes, como aponta Marx em $O$ capital quanto à práxis dos "agentes da produção", “eles não sabem disso, mas o fazem.” (MARX, 2013, p. 208) O processo de valorização do valor tratado na obra magna de Marx tem por trás de si o processo de trabalho. Ao mesmo tempo, este último é eclipsado: justamente a sociedade que tem a universalização do trabalho enquanto abstração (Cf. MARX, 2011) é aquela em que o papel da atividade do homem nas relações sociais aparece ofuscado. E, se o trabalho é de grande relevo na Ontologia lukacsiana (Cf. SARTORI, 2010 a), é bom deixar claro que o processo pelo qual este deixa de ser central na cotidianidade é também tematizado pelo autor húngaro. (Cf. FORTES, 2016)

Diante das circunstâncias que marcam a reprodução do capital, os nexos causais produzidos pela atividade humana - cuja protoforma está no trabalho, segundo Lukács (Cf. LUKÁCS, 2013) - são vistos, não só enquanto marcados por certa alienação (Entäusserung) - ou seja, pelo fato de os nexos objetivos produzidos pelo próprio homem ultrapassarem suas existências individuais e colocarem-se objetiva e autarquicamente no mundo diante da prática consciente, mas também pelo estranhamento (Entfremdung) ${ }^{8}$ desta prática, tendo-se, com o último fenômeno, potências produzidas pelo próprio homem se voltando contra ele, como potências objetivas e

\footnotetext{
${ }^{7}$ A percepção acerca deste fenômeno não seria exclusividade do marxismo. Em verdade, importantes filósofos não marxistas, como Heidegger, teriam tido uma análise aguçada da questão (do estranhamento). No entanto, teriam incorrido no erro de considerar um aspecto essencialmente histórico e, como tal, suprimível, como uma espécie de "condição humana": "para a crítica filosóficoburguesa da civilização - basta pensar em Heidegger -, era muito óbvio sublimar a crítica social numa crítica puramente filosófica, fazer do estranhamento, social em sua essência, uma conditione humaine eterna, para utilizar o termo que surgirá só mais tarde." (LUKÁCS, 2003, p. 26)

${ }^{8}$ Sobre este ponto, aponta Tertulian: "importância capital de distinguir alienação e objetivação". (TERTULIAN, 2006, p. 30) É importante ressaltar ainda nessa seara que, como destacou Ronaldo Vielmi: "Lukács identifica a presença de dois fatores fundamentais da dinâmica autoconstitutiva do homem: as categorias da objetivação (Vergegenständlichung) e a alienação (Entäusserung)." (FORTES, 2012, p. 70) Ou seja, para Lukács, a alienação é constitutiva da práxis social, ao passo que o estranhamento é um produto social passível de supressão (Aufhebung) pela práxis que remete para além da sociabilidade presente, para que se use a dicção deste artigo, para além da "generidade em-si". Veja-se a importância da questão para Lukács o que toca a própria construção do socialismo e a superação da "generidade em-si": "socialismo: recuo do estranhamento pela extensão da objetivação - lugar d. Ética." (LUKÁCS, 2015, p. 63); "socialismo como recuo do estranhamento (pelo desenvolvimento da
} vol.10, nº. 03, Rio de Janeiro, 2017.pp. 1582-1609 
hostis a seu desenvolvimento. (Cf. ALCÂNTARA, 2014) Este surgir, como apontado acima, "independentemente das representações e da vontade dos homens" está relacionado justamente a isso, e ao fato, também trazido acima, de que "o produto da sumarização efetuada espontaneamente pela sociedade a partir das consequências causais dos pores teleológicos no trabalho" conforma, na sociedade capitalista, uma forma de universalidade estranhada e marcada pela ausência de controle consciente das condições de vida. ${ }^{9}$ Trata-se daquela universalidade que Lukács chamou de generidade em-si. (Cf. VAISMAN, 2009) Ela perpassa a "préhistória da sociedade humana" (MARX, 2009, p. 48), a "história de todas as sociedades que existiram", "a história da luta de classes". (MARX; ENGELS, 1998, p. 9) Ao que Lukács acrescenta, de modo direto: "em certo sentido se poderia dizer que toda a história da humanidade, a partir de um determinado nível da divisão do trabalho (talvez já daquela da escravidão), é também a história do estranhamento humano." (LUKÁCS, 1981, p. 569). No que, com isso, tem-se uma equação importante: segundo Lukács, a generidade em-si é marcada pela autonomização de potências estranhadas. Elas se impõem na vida cotidiana, como dito acima, "independentemente das representações e da vontade dos homens" e se apresentam como uma espécie de condição humana inelutável. ${ }^{10} \mathrm{E}$ o tratamento desta questão, segundo o autor, perpassaria a ética: "socialismo: recuo do estranhamento ${ }^{11}$ pela extensão da objetivação (Vergegenstandlichung) - lugar d. Ética." (LUKÁCS, 2015, p. 63) Ou seja, na ética, simultaneamente, Lukács procura criticar uma forma de universalidade marcada pelo domínio do capital e não deixa de lado o modo pelo qual, com base na superação (Aufhebung) desta universalidade, seria possível remeter para além da pré-história da sociedade humana. Se, para alguém como Althusser a noção de Aufhebung só poderia ser daninha, Lukács, também ao tratar da questão da generidade, traz a temática como central, trazendo uma leitura marxista da questão. ${ }^{12}$

objetivação e alienação): Ética." (LUKÁCS, 2015, p. 79)

${ }^{9}$ Segundo Marx, de quem Lukács parte, "a figura do processo social da vida, isto é, do processo da produção material apenas se desprenderá do seu véu místico quando, como produto de homens livremente socializados, ela ficar sob seu controle consciente e planejado." (MARX, 1988, p. 76)

${ }^{10}$ Agnes Heller, ainda marcada pela influência lukacsiana, aponta que "a vida cotidiana de todas as esferas da realidade é aquela que mais se presta ao estranhamento." (HELLER, 1972, p. 37) Para um tratamento mais detido da questão, Cf. ALCÂNTARA, 2014; SARTORI, 2012, 2016 b, 2010 b.

${ }^{11}$ Aqui, modificamos a tradução de alienação por estranhamento para dar homogeneidade à tradução. Cabe trazer aqui o que traz Lukács: "a objetificação é um tipo natural - positivo ou negativo, conforme o caso - do domínio humano sobre o mundo ao passo que o estranhamento representa uma variante especial que se realiza sob determinadas circunstâncias sociais." (LUKÁCS, 2003, p. 46) Ou seja, não é toda a atividade humana que é estranhada, mas só aquela que perpassa a generidade em-si e o reforça, de modo a obstacularizar a superação da "pré-história da sociedade humana".

${ }^{12}$ Althusser critica a concepção hegeliana justamente por estar marcada pelo Aufhebung, tratando-se de algo indissociável da "negação da negação". Lukács, por seu turno, é muito crítico quanto à negação da negação ao mesmo tempo em que faz uma leitura crítica da noção de Aufhebung. Veja-se Althusser: "o que macula irremediavelmente a concepção hegeliana da história como processo dialético é a concepção teleológica da dialética, inscrita nas próprias estruturas da dialética hegeliana, num ponto extremamente preciso: a Aufhebung (ultrapassagem-conservando-o-ultrapassado- como-ultrapassado-interiorizado), expressa diretamente na categoria hegeliana da negação da negação (ou negatividade)." (ALTHUSSER, 1979, p. 69) Para o autor, as concepções de Lukács estariam "contaminadas por um hegelianismo vergonhoso" (ALTHUSSER, 1979, p. 100) De nossa parte, acreditamos que a questão é bastante distinta, até mesmo porque a crítica a Hegel é central à conformação da noção de ontologia vol.10, n. 03, Rio de Janeiro, 2017.pp. 1582-1609 
A produção capitalista, que dá a forma mais acabada da generidade em-si e à história mundial, para Lukács, é uma forma de produção estranhada em que emerge uma universalidade eivada pela ausência do controle consciente das condições de vida dos homens. Em meio a ela, impera certa espontaneidade que marca a esfera produtiva capitalista, no limite, trazendo hábitos que são essenciais na mediação entre a determinação econômica do ser social e os diversos complexos sociais que se colocam meio à reprodução social. (Cf. LUKÁCS, 2013)

No capitalismo, a criação do hábito significa, assim, um processo geral de obscurecimento. Os homens concebem a espontaneidade como natural e normal, e aprendem a reagir às suas manifestações tal como se reage a um temporal ou ao calor intenso, isto é, a eventos naturais que podem certamente ser desagradáveis, e que podemos eventualmente detestar, mas que devem ser considerados tais como são. (LUKÁCS, 2010 b, p. 118)

O hábito, que, em verdade, é central à eticidade (Sittlichkeit), juntamente com a vida cotidiana (Cf. SARTORI, 2010 b), é um importante elo intermediário na reprodução do ser social, colocando-se entre as relações objetivas que marcam a economia e as relações, por assim dizer, superestruturais. A espontaneidade ganha muito destaque no campo das relações de produção, certamente. ${ }^{13}$ Lukács, porém, aponta que o mesmo não se dá necessariamente com o campo do Direito, ao menos, não do mesmo modo: se o complexo jurídico não pode ser dissociado das contradições e dos antagonismos sociais que marcam, depois de determinado momento da história humana, a existência da sociedade civil-burguesa (Cf. SARTORI, 2010 a), ele, enquanto complexo social específico, também não se confunde com essas contradições, tratando-se - caso se queira compreender a real e efetiva tessitura do ser social - de analisar a heterogeneidade entre o Direito, a política e a esfera econômica. (Cf. SARTORI, 2016 a) Um dos aspectos que traz a especificidade do jurídico passa justamente pelo fato segundo o qual, segundo o autor da Ontologia, como colocado acima, "no sistema jurídico, esses princípios de regulação constituem resultados de um pôr consciente, que enquanto pôr deve determinar as factualidades." E a questão é bastante meandrada: ao mesmo tempo em que, como aponta Marx, "o Direito nada mais é que o reconhecimento oficial do fato" ${ }^{14}$, (MARX, 2004, p. 84) o caráter não simplesmente epifenomênico do Direito é

\footnotetext{
lukacsiana. (Cf. SARTORI, 2016b)

${ }^{13}$ Como aponta Marx em $O$ capital, "no evolver da produção capitalista desenvolve-se uma classe de trabalhadores que, por educação, tradição e hábito, reconhece as exigências desse modo de produção como leis naturais e evidentes por si mesmas." (MARX, 2013, p. 808) Marx, assim, destaca justamente esta mediação que estamos destacando e que Lukács, em diálogo crítico com Hegel, chamou de eticidade.

${ }^{14}$ Sobre a questão, aponta Lukács: "o fato de o sistema vigente do Direito positivo e a factualidade socioeconômica na vida cotidiana subsistirem lado a lado e se encontrarem ao mesmo tempo emaranhados leva necessariamente aos mais diversos tipos de más interpretações da relação entre ambos. Polemizando contra tal teoria errada de Proudhon e em conformidade com a constatação da prioridade ontológica e da legalidade própria dos processos econômicos, Marx propôs a seguinte definição: ' $\mathrm{O}$ Direito é apenas o reconhecimento oficial do fato' recém-constatada do econômico. Essa definição quase aforística é extremamente rica em conteúdo, contendo já os princípios mais gerais daquela discrepância necessária entre Direito e realidade econômicosocial[...]. A determinação 'o fato e seu reconhecimento' expressa com exatidão a condição de prioridade ontológica do econômico: o Direito constitui uma forma específica do espelhamento, da reprodução consciente daquilo que sucede de fato na vida econômica. A expressão 'reconhecimento' apenas diferencia ainda mais a peculiaridade específica dessa reprodução, ao trazer para
} vol.10, nº. 03, Rio de Janeiro, 2017.pp. 1582-1609 
claro. Este complexo social é resultado de um pôr consciente que, no limite, determina as factualidades - e neste ponto vale destacar: o aspecto jurídico é um elo necessário, e posto de modo consciente, entre as possibilidades presentes em meio à sociabilidade capitalista e a efetividade das distintas potencialidades contidas nelas. Justamente neste complexo, em meio à reprodução do complexo social total, aparece como central a relação entre possibilidade e realidade efetiva (Wirklichkeit), tão central ao último Lukács ao se contrapor a Hegel. (Cf. TERTULIAN, 2016; SARTORI, 2016 d). Neste sentido, tendo-se em conta esta relação destacada pelo marxista húngaro, pode-se apontar que o Direito traz consigo certa multivocidade da sociedade, ao mesmo tempo em que esta multivocidade mesma está amparada em uma forma de universalidade, aquela que Lukács chamou de generidade em-si.

O Direito, para Lukács, determina as factualidades na medida em que é um elo entre as possibilidades presentes no grau de desenvolvimento social marcado pela sociabilidade capitalista e a efetividade desta sociedade, não podendo remeter, em seu ser-propriamente-assim, para além dela. (Cf. SARTORI, 2010, 2014, 2015 b, 2016 a) A outra qualidade que menciona Lukács ao tratar do Direito, traz um duplo aspecto: de um lado, ela se apresenta ao passo que o complexo jurídico opera por meio de pores teleológicos secundários (relacionados à transformação dos próprios homens, e não da natureza) elaborados a partir de uma posição específica na divisão do trabalho (Cf. SARTORI, 2010 a) - neste sentido, a espontaneidade que aparece como algo natural no campo econômico, mesmo em meio a relações sociais absolutamente irracionais, não tem lugar no Direito, ao menos não de imediato. ${ }^{15}$ Ao mesmo tempo, isso não significa que o complexo jurídico possa se colocar acima da generidade em-si; antes, há algo que, indissociável dele, busca, sem nunca poder elevar-se acima deste nível de generidade: as críticas às chamadas injustiças. Lukács é explícito ao apontar que "a justiça que emerge daí consta, por sua vez, no rol dos conceitos mais ambíguos no desenvolvimento humano. ” (LUKÁCS, 2013, p. 244). Ou seja, em meio à especificidade da generidade em-si, têm-se tendências, inseparáveis da existência do próprio Direito que intentam, segundo o autor, sem nunca poderem, colocar-se para além desta etapa de desenvolvimento das relações sociais que se apresenta no que chamou de história do estranhamento humano.

No limite, como apontou Lukács acima, tem-se que aquilo chamado acima de "imposição formalmente consequente da lei" pode muitas vezes trazer consigo, tanto no campo popular, quanto no dos juristas, uma crítica ao Direito, crítica esta que permanece no terreno do Direito ao apelar à noção de justiça e ao se contrapor às

o primeiro plano seu caráter não puramente teórico, não puramente contemplativo, mas precipuamente prático." (LUKÁCS, 2013, p. 237-238)

${ }^{15}$ Aponta Marx sobre estas mediações econômicas na sociedade capitalista: "as mediações das formas irracionais em que determinadas condições econômicas aparecem e praticamente se acoplam não importa nem um pouco para os portadores práticos dessas condições econômicas em sua ação diuturna; e já que eles estão acostumados a se movimentar no meio delas, não ficam nem um pouco chocados com isso. Uma perfeita contradição não tem nada de misterioso para eles. Nas formas fenomênicas que perderam a coerência interna e que, tomadas em si, são absurdas, eles se sentem tão à vontade como um peixe na água." (MARX, 1985, p. 241) 
injustiças. (Cf. SARTORI, 2017). Ou seja, na própria estrutura do complexo jurídico, tem-se certa tensão entre o Direito positivo e a noção de justiça. No próprio funcionamento prosaico do complexo jurídico tem-se espaço para a crítica ao seu funcionamento, sendo essencial não tanto a constatação desta possibilidade, mas enxergar as potencialidades dela.

O problema social real que perpassa o Direito é tratado por Lukács ao passo que há uma oposição entre Direito e justiça ao mesmo tempo em que esta oposição não poderia ser resolvida seja por um, seja por outro. (Cf. SARTORI, 2017) A questão, no limite, para o autor húngaro, remete à ética. Não só porque, como disse acima Lukács, "o fato de que nenhum Direito pode subsistir se não puder ser efetivado mediante a coerção, mas que para que o seu funcionamento se dê com o mínimo de friç̧ão é preciso que haja certa consonância entre seus vereditos na opinião pública"; tem-se também algo muito próximo ao que foi colocado e que aparece na Estética e que deixa a questão ainda mais explícita: "um sistema jurídico não pode funcionar muito tempo se não tem nada a ver com as concepções éticas de um povo. A afirmação oposta parte de uma abstração conceitual e historicamente falsa." (LUKÁCS, 1966, p. 220) A consonância com a opinião pública, em verdade, está bastante relacionada com as concepções éticas de um povo, de tal modo que a questão destaca o fato segundo o qual o sistema jurídico não pode, sob nenhum aspecto, ser visto como algo que se sustenta por si. (Cf. SARTORI, 2010 a). Há, claro, uma determinação bastante real dos limites das possibilidades da atuação do Direito e que está presente, com diversas mediações, na dimensão econômica da sociabilidade. (Cf. LUKÁCS, 2013) Por isso, o solo sobre o qual se coloca o complexo jurídico não pode deixar de ser econômico; no entanto, diz Lukács, há um modo de relação com o Direito distinto daquele que se dá diante da economia, como trazido acima: "as reações sociais a ele também acabam sendo necessariamente de outra qualidade" na medida em que há uma mediação importante entre a esfera econômica e a jurídica, aquela da ética (e da eticidade). Por isso, o estudo do projeto lukacsiano acerca de uma ética ganha relevo. Justamente ao passo que há uma real e efetiva discrepância entre o ser-propriamenteassim (Geradesosein) da sociedade e o Direito isso se dá (Cf. SARTORI, 2010 a); a dimensão da eticidade, segundo Lukács, é este elo mediador, que precisaria ser estudado com cuidado para uma real e efetiva crítica ontológica. Para que não se veja o abismo entre uma coisa e outra como uma condição humana, seria importante estudar a complexa relação entre Direito, ética e a generidade em-si, por conseguinte. Diz Lukács:

Para Hegel, [...] a inteira moralidade é tão somente uma parte da práxis humana que encaminha para a autêntica eticidade. E o dever-ser tem um significado real apenas enquanto expressa a defasagem entre a vontade humana e "o que é em-si". Na eticidade, essa defasagem é superada e, por conseguinte, o posto central do dever-ser é eliminado também no mundo da práxis. A profunda correção e a igualmente profunda problematicidade dessa posição só poderão ser adequadamente discutida na Ética. (LUKÁCS, 2012, p. 189)

Lukács traz como central a crítica ao posto central do dever-ser, que remete à certa centralidade da problemática moral e, em essência, segundo o autor, ligada a alguma forma de autoconsciência, tipicamente colocada no kantismo. Ao trazer a eticidade à tona, o marxista procura destacar o modo pelo qual justamente a 
discrepância entre o ser-propriamente-assim da sociedade e concepções que trazem por central o momento do dever-ser não pode ser resolvida com uma concepção jurídica ou moral de mundo (Cf. SARTORI, 2015 b); e, deste modo, justamente, a questão só poderia ser adequadamente discutida na Ética, também, ao se criticar a concepção hegeliana de eticidade, que estaria marcada por certo logiscismo e por uma concepção teleológica de história. (Cf. LUKÁCS, 2012) A defasagem e a discrepância apontadas pelo autor, pois, remetem tanto à compreensão da especificidade de cada complexo social, quanto à relação de cada um deles com a totalidade social, no capitalismo, colocada sob a égide do capital e, para que se use a dicção do autor, da generidade em-si. A questão pode ser desenvolvida tendo em conta diversas esferas do ser social. Aqui, porém, atém-se à relação entre Direito, ética e generidade.

O modo pelo qual esta discrepância social se apresentaria e a maneira pela qual isso se mostra, inclusive politicamente, por exemplo, não podem ser tratadas neste momento. Elas remetem à relação entre a figura política do liberalismo, à centralidade da moral na normatividade colocada sobre a generidade em-si e, ao fim, à necessidade de se buscar a superação desta generidade passando pela ética. (Cf. SARTORI, 2016 a). É bom destacar desde já, porém: para Lukacs, a superação deste abismo não remete à valorização da moral ou da política, como ocorre na sociedade capitalista ou mesmo no stalinismo - diz o marxista húngaro: "stalinismo reconversão da moral em Direito. Paralisia. Dificuldade do pôr a questão ética" (LUKÁCS, 2015, p. 175); "Stalin: moral retorna ao Direito ao invés de avançar para a ética (consequência: reservatio mentalis, auto-enganação etc, foi pelo Direito naturalmente, quer pela distorção moral)." (LUKÁCS, 2015, p. 171) ${ }^{16}$ - antes, ela passa por uma problematização do próprio estágio de desenvolvimento social em que se está, aquele da generidade em-si. Assim, sem um posicionamento pela supressão e superação desta, e do próprio Direito (Cf. SARTORI, 2010 a), segundo Lukács, girar-se-ia em círculos ao tratar deste abismo e desta discrepância social, de tal modo que, como disse acima, "aquilo que de modo geral é sentido como injustiça" só poderia ser visto com o devido cuidado tendo em mente a relação entre moral, ética, Direito e a generidade em-si.

Ou seja, para o autor húngaro que aqui analisamos, não se trataria tanto de buscar opor a justiça ao Direito, mas de enxergar que uma e outra operam como determinações reflexivas no funcionamento real e efetivo do Direito. (Cf. SARTORI, 2017). Ao que tudo indica, as questões que são colocadas por meio da noção de justiça, em Lukács, ainda trazem consigo certo posto central do dever-ser, sendo que o oposto seria necessário: um

\footnotetext{
${ }^{16}$ Para Lukács, o stalinismo cometeu equívocos teóricos imperdoáveis no que diz respeito ao tratamento do Direito: "nessa questão, o marxismo vulgar não foi além da declaração de uma dependência niveladora, mecânica, em relação à infraestrutura econômica (o neokantismo e o positivismo do período revisionista representaram um castigo justo da história por essa vulgarização). O período stalinista, por sua vez, exacerbou novamente essa concepção mecanicista e a transpôs para a práxis social pela força; os resultados são conhecidos de todos." (LUKÁCS, 2013, p. 249) A luta de guerrilha de Lukács contra o stalinismo incluía, inclusive, a elaboração de uma Ética: "minha luta guerrilheira contra o dogmatismo não apenas salvou a minha relação com a vida e seus objetos, mas também a promoveu. Se hoje posso trabalhar numa estética e sonhar com a elaboração de uma ética, devo-o a esta luta." (LUKÁCS, 2008, p. 51)
} 
enfoque no modo pelo qual seria preciso pensar na necessidade de supressão da generidade em-si na generidade para-si por meio da atividade humana. E esta, como se vê pelo que trazemos, é uma das principais questões para uma Ética, em que a relação entre a atividade humana, as determinações da realidade efetiva e a especificidade de cada complexo social ganham destaque e se sobrepõe sobre o posto central do dever-ser. Este último ampara-se na moralidade e implica na hipostasia da dimensão deontológica.

A reconciliação da interioridade - relacionada, sobretudo, à moral, e aquilo que, contra a universalidade do Direito, como dito acima, "é sentido como injustiça" - é justamente uma das questões que Lukács também estudaria em sua Ética. E, neste sentido, ganha relevo a posição lukacsiana segundo a qual "pode-se dizer que a ética constitui nas práticas humanas um centro mediador entre o Direito puramente objetivo e a moralidade puramente subjetiva." (LUKÁCS, 1966, p. 220). Percebe-se, assim, certa importância decisiva que o autor da Ontologia dá à questão da ética a qual, pelo que estamos trazendo, aparece como algo essencial ao passo que implica na problemática da generidade. Mesmo que o autor não tenha chegado a desenvolver uma Ética, é possível notar que questões essenciais à sua teoria e aos próprios rumos da sociedade capitalista de sua época vêm a remeter a ela e ao modo pelo qual a teorização sobre a generidade ganha destaque na obra lukacsiana. Sobre isto, coloca o autor na primeira parte de sua Ontologia algo essencial:

Por mais fragmentária que seja esta nossa exposição - e ela não poderia deixar de sê-lo, a não
ser que pretendêssemos antecipar, de maneira inadequada, as questões que só poderão ser
discutidas de modo conveniente na segunda parte ou mesmo na ética -, não podemos
concluílla sem pelo menos começar a delinear um problema ontológico do
desenvolvimento geral do ser social, no qual se expressa um novo aspecto tanto da
historicidade desse último quanto do progresso objetivo que nela tem lugar: o problema do
gênero humano. (LUKÁCS, 2012, p. 395)

Questões que, de modo conveniente, só poderiam ser discutidas na Ética se apresentam justamente ao passo que Lukács levanta um tema central a sua obra madura: o problema do gênero humano. (Cf. VAISMAN, 2009). No que se tem um duplo aspecto: o autor não desenvolveu sua Ética, restando somente apontamentos para que se elaborasse a mesma (Cf. LUKÁCS, 2015); no entanto, deixou claro que há algumas questões centrais a serem abordadas nesta: o gênero humano (correlacionado à relação entre generidade em-si e para-si), o Direito, a moral e, claro, a especifidade da eticidade. Deste modo, uma tarefa necessária àqueles que procuram compreender o legado lukacsiano é justamente tratar dos meandros que permeiam esta difícil questão. Como mencionado, por este caminho também é possível desenvolver uma crítica marxista ao Direito distinta daquela que vem sendo desenvolvida no Brasil sob auspícios althusserianos.

\section{ACERCA DA ESPECIFICIDADE DA ÉTICA DIANTE DO DIREITO}

Por mais que Lukács vá se ater à especificidade de cada complexo social e, com isso, à especificidade do Direito, é necessário destacar que, em meio a este empenho do marxista húngaro, não está descartado tratar das vol.10, nº. 03, Rio de Janeiro, 2017.pp. 1582-1609 
tensões propiciadas em cada esfera do ser social. Ou seja, justamente ao passo que se procura entender aquilo que caracteriza cada complexo é que aparecem as tensões e as contradições que permeiam os mesmos. Se o autor húngaro reconhece que o fenômeno jurídico não se sustenta em si próprio, é preciso que se diga que, em meio ao desenvolvimento, por assim dizer, interno deste complexo parcial, foram várias as tentativas de trazer à tona um fundamento do Direito, fundamento este que, no limite, parecia - ao menos aos juristas e àqueles que tomam o Direito como algo central a uma crítica social - poder se contrapor à própria realidade efetiva do Direito positivo. Tal aspecto, acreditamos, é essencial à compreensão da particularidade real e efetiva da esfera jurídica; e Lukács não deixa de ter isto em conta. Com isto, têm-se, correlatas, duas teorizações: a primeira delas com a busca por um Direito natural e outra, que tem como elo norteador a questão da justiça, questões estas as quais são importantes nos embates que caracterizam a teoria e a filosofia do Direito. (Cf. SARTORI, 2015 b) ${ }^{17}$ Pelo que vimos, no entanto, segundo Lukács, a questão se apresenta de um modo peculiar: o elo que liga o Direito positivo a seu funcionamento real e efetivo da sociedade é aquele daquilo que chamou acima de "concepções éticas de um povo", sendo um fato, inclusive, no que toca o Direito positivo, como se disse acima, que: para que "o seu funcionamento se dê com o mínimo de fricção é preciso que haja certa consonância entre seus vereditos na opinião pública". Ou seja, o fundamento procurado no campo jurídico estaria longe de ser transcendente, ou normativo em termos de um sistema de dever social em que se tivesse o posto central do dever-ser; antes, este posto central, segundo Lukács, com referência à eticidade, como dito acima, "é eliminado também no mundo das práxis", de tal forma que se tem uma contraposição clara entre a concepção lukacsiana e aquela da teoria do Direito.

Ao passo que a última remete a uma teoria moral e a uma teoria sobre a justiça, a concepção lukacsiana subordina estas questões à ética, remetendo à conformação real e efetiva da eticidade. Esta tensão - entre Direito, justiça e Direito natural - não passa despercebida e é destacada por Lukács do seguinte modo:

A fim de promover a mediação entre Direito e necessidade de justiça, a reflexão sobre o Direito produz, por seu turno, a concepção peculiar do direito natural, igualmente um sistema do dever social, cujo pôr, no entanto, objetiva alçar o seu sujeito acima do estado concreto de Direito existente em cada oportunidade. Esse sistema, dependendo das necessidades da época, é concebido como determinado por Deus, pela natureza, pela razão etc. e, por isso, deve estar capacitado para ultrapassar os limites impostos pelo Direito positivo. Como Kelsen reconheceu corretamente, as duas tendências têm trajetos paralelos: intenção, finalidades etc. de uma facilmente continuam nas de outra, pois ambas devem almejar, sem ter consciência crítica de si mesmas, na mesma medida, um estágio da generidade mais elevado do que o realizável no Direito positivo. Só na Ética será possível expor por que nem a complementação pela moral nem todas as iniciativas reformistas no Direito natural e a partir dele foram capazes de elevar o Direito acima do nível de generidade

\footnotetext{
${ }^{17}$ Para que fiquemos em autores paradigmáticos, pode-se apontar que positivistas como Kelsen (2003) e Hart (2003) a atacaram com bastante força, mesmo que de modo distinto, tanto a questão da justiça quanto aquela de um suposto direito natural; autores como Dworkin (2007; 2005), por seu turno, buscaram teorizar sobre a justiça ao passo que rechaçaram a crítica segundo a qual, ao fazê-lo, cairiam em uma concepção jusnaturalista.
} 
que lhe é inerente. Nesse ponto, só podemos apontar para o fato de que o sonho de justiça inerente a todas essas exigências, enquanto ele precisar ser e for concebido nos termos do Direito, não poderá levar além de uma concepção - em última análise, econômica - de igualdade, da igualdade que é determinada de modo socialmente necessário a partir do tempo de trabalho socialmente necessário e que se concretiza no intercâmbio de mercadorias, tempo de trabalho socialmente necessário que deve permanecer como base real e, por essa razão, insuperável no pensamento, de todas as concepções jurídicas de igualdade e justiça. A justiça que emerge daí consta, por sua vez, no rol dos conceitos mais ambíguos no desenvolvimento humano. Ela assume a tarefa, para ela insolúvel, de harmonizar idealmente ou até institucionalmente a diversidade e peculiaridade individual dos homens com o julgamento dos seus atos com base na igualdade produzida pela dialética do próprio processo da vida social. (LUKÁCS, 2013, p. 242-243)

Temas destacados acima, no item anterior deste texto, aparecem novamente na passagem, e de modo claro. A correlação entre Direito, generidade em-si e a impossibilidade de a esfera jurídica ou moral serem vistas enquanto resolutivas se destacam na citação, a qual, também, vem a destacar que a questão, ligada às tensões que permeiam o ser-propriamente-assim do Direito, somente poderiam ser resolvidas na Ética. Algo a ser destacado também é a crítica lukacsiana à justiça, que, correlacionada ao Direito, nunca poderia remediar as limitações deste, já que ele estaria ligado ao processo de valorização do valor, em que o trabalho abstrato e calcado no tempo de trabalho socialmente necessário aparece enquanto um elo necessário à reprodução social. (Cf. MARX, 2013; LUKÁCS, 2013, 2012). Esta seria a base real sobre a qual se coloca realmente o Direito, de modo que a maneira mediante o qual se coloca a especificidade do complexo jurídico é inseparável do processo de intercâmbio de mercadorias (Cf. SARTORI, 2017), o qual, depois de determinado grau de desenvolvimento social, tem como solo a perpetuação da relação-capital ${ }^{18}$, que é o real fundamento sobre a qual se coloca aquilo que Lukács chama de generidade em-si.

Deste modo, ao mesmo tempo em que o Direito traz consigo como base ineliminável a pré-história do gênero humano, a história da luta de classes e do estranhamento do homem, ele se volta contra isso peculiarmente. A tensão que emerge disso é destacada pelo autor da Ontologia.

Aquilo visto como uma “necessidade de justiça”, segundo Lukács, em abstrato, não faz parte do Direito há uma concepção específica de justiça que permeia a esfera de acordo com o ser-propriamente-assim desta; embora exista real e efetivamente uma correlação entre justiça, igualdade e a esfera jurídica, há de se destacar isto. A contraparte do Direito positivo, neste sentido, é o Direito natural, de modo que ambos, em verdade, são indissociáveis ao mesmo tempo em que não se reduzem um ao outro, tratando-se de determinações reflexivas. (Cf. SARTORI, 2010 a) Trata-se de dois sistemas de dever-social os quais, enquanto dever-ser (Sollen), somente

\footnotetext{
${ }^{18}$ Diz o autor de $O$ capital que "a relação-capital pressupõe a separação entre os trabalhadores e a propriedade das condições de realização do trabalho. Tão logo a produção capitalista se apoie sob os próprios pés, não apenas conserva tal separação, mas a reproduz em escala sempre crescente. Portanto, o processo que cria a relação-capital não pode ser outra coisa que não o processo de separação entre o trabalhador e a propriedade das suas condições de trabalho, um processo que por um lado transforma os meios sociais de subsistência e de produção em capital, por outro, os produtores imediatos em operários assalariados." (MARX, 1987, p. 252)
} 
podem ser efetivos em meio à correlação entre pores teleológicos e as potencialidades presentes no próprio real (Reale), este último, marcado por contradições que só poderiam ser resolvidas por meio da transformação real e efetiva da tessitura da sociedade. (Cf. ANDRADE, 2016) A justiça correlacionada ao complexo jurídico, pois, tem uma caracterização dúplice: traz uma concepção de Direito, mais precisamente, um Direito natural, que, como disse Lukács acima, "deve estar capacitado para ultrapassar os limites impostos pelo direito positivo" e, ao mesmo tempo, apega-se - devido à sua própria conformação objetiva (Cf. SARTORI, 2014) - à igualdade que emerge desta concepção e, assim, nunca pode ultrapassar a especificidade da generidade em-si. Para o autor, o complexo jurídico como um todo está correlacionado ao tempo de trabalho socialmente necessário e, portanto, à lei do valor, não sendo possível também neste sentido, mantendo as determinações reais e efetivas do Direito, remeter para além da generidade em-si. O marxista húngaro mostra, assim, como que a igualdade jurídica e valorização do valor se correlacionam de modo bastante mediado, necessitando de elos intermediários dotados de certa autonomia relativa, como por exemplo uma concepção - em última instância econômica e relacionada ao intercâmbio de mercadorias - de justiça e de igualdade.

Ou seja, ao mesmo tempo em que há uma ligação indissolúvel entre o Direito e o processo de valorização do valor - efetivado no processo de intercâmbio mercantil (algo bastante destacado por Pachukanis) - este processo mesmo necessita, por vezes, de uma situação em que os homens "não sabem disso, mas o fazem", para que se use a expressão de Marx de $O$ capital, já citada - acreditam opor-se a algo ao passo que, até certo ponto, o reafirmam. Ou seja, segundo o autor da Ontologia, justamente ao procurar se voltar contra o Direito existente em determinado momento é que as determinações da esfera jurídica se afirmam cabalmente, também, com referência a uma espécie de Direito natural, de justiça ou, no limite, de justiça das transações. ${ }^{19}$ Um dos grandes méritos da análise de Lukács - em suas últimas obras - neste ponto é apreender esta tensão em seus meandros e em seus nuances; ao mesmo tempo em que não desconsidera a relação da esfera jurídica com a circulação mercantil e com a lei do valor, o marxista húngaro não reduz o Direito a este aspecto, procurando compreender a real tessitura desta esfera do ser social em sua conformação complexa e multifacetada. Lukács é bastante claro em sua crítica ao Direito (Cf. SARTORI, 2010, 2014, 2015 b) ao mesmo tempo em que isto não significa que o autor deixe de analisar com cuidado aquilo que supostamente - somente supostamente - remete para além do grau de generidade que o complexo social jurídico pode propiciar.

Ele ressalta a necessidade, que permeia o complexo jurídico, para que se use suas palavras citadas acima,

\footnotetext{
${ }^{19}$ Veja-se o que diz Marx sobre esta última em $O$ capital: "a justiça das transações que se efetuam entre os agentes da produção baseia-se na circunstância de se originarem das relações de produção como consequência natural. As formas jurídicas em que essas transações econômicas aparecem como atos de vontade dos participantes, como expressões de sua vontade comum e como contratos cuja execução pode ser imposta à parte individual por meio do Estado não podem, como simples formas, determinar esse conteúdo. Elas apenas o expressam. Esse conteúdo será justo contanto que corresponda ao modo de produção, que lhe seja adequado. E injusto, assim que o contradisser. A escravatura, na base do modo de produção capitalista, é injusta; da mesma maneira
} vol.10, no. 03, Rio de Janeiro, 2017.pp. 1582-1609 
de "promover a mediação entre Direito e necessidade de justiça", de modo que, ao menos nessa passagem, a noção de justiça não aparece, em um sentido bastante específico, completa e necessariamente ligada à reprodução da relação-capital. A Lukács, até certo ponto, parece mesmo haver certo potencial relacionado a uma concepção de justiça que se colocassem para além "de todas as concepções jurídicas de igualdade e justiça”, como mencionado acima; ou seja, é preciso ter e conta uma tensão específica que se põe no modo pelo qual se coloca real e efetivamente o Direito, em especial, na sociedade capitalista; nesta última, a noção de justiça parece trazer uma crítica decisiva ao Direito positivo ao mesmo tempo em que isto, em verdade, seria impossível; isto, porém, não significa que esta crítica não pudesse remeter - ao deixar de ter por central a elaboração de outro sistema de dever social - a questões essenciais para a compreensão da real tessitura do Direito. Isto, de certo modo, pode ser relacionado à tensão presente no Direito entre o Direito natural e o Direito positivo, tensão esta que permeia a noção de justiça - a temática aparece na obra do autor húngaro ao passo que, tanto quanto à justiça, quanto em relação às concepções de Direito natural, Lukács diz na passagem já citada acima: "ambas devem almejar, sem ter consciência crítica de si mesmas, na mesma medida, um estágio da generidade mais elevado do que o realizável no Direito positivo." Também neste ponto, eles não sabem disso, mas o fazem.

Ou seja, mesmo que, com a concepção de justiça, tenha-se eventualmente um contraponto ao Direito, esta contraposição, segundo o Lukács da Ontologia, nunca poderia ser efetivamente marcada por uma consciência crítica e, deste modo, tem-se uma situação peculiar, em que se almeja, sem nunca poder ultrapassar real e efetivamente a especificidade da generidade em-si. Neste sentido específico, a concepção de justiça não se atém de imediato à relação-capital, mas, de um modo meandrado, a supõe, colocando-se de modo mediado. Lukács destaca algo essencial: tem-se conjuntamente um ímpeto legítimo na busca de um estágio da generidade mais elevado do que o realizável no Direito positivo e a impossibilidade de, com essas bases - aquela do Direito natural e da justiça - alcançá-lo. Seria necessário dar um passo noutra direção, o da crítica ao Direito.

O modo pelo qual opera o ideal de justiça, bem como o Direito natural, segundo o autor da Ontologia, não é aquele em que se busca a superação de uma sociabilidade específica, mas de um outro sistema de dever social. Ou seja, mantém-se intacto o posto central atribuído à dimensão do dever-ser, de tal forma que, na melhor das hipóteses, tem-se uma espécie de reconhecimento que opera por meio de uma tentativa malograda de harmonização das vicissitudes que marcam um modo de produção essencialmente, e não contingentemente, conflituoso e marcado pelo antagonismo classista. Deste modo, longe de a noção de justiça e de o Direito natural retirarem de campo o posto central do dever-ser, este último é reafirmado, de modo acrítico, sem se ter uma espécie de consciência crítica, segundo Lukács, essencial em qualquer contraposição ao Direito positivo. A busca por um estágio da generidade mais elevado do que o realizável no Direito positivo, deste modo, por meio do 
Direito natural e da justiça, só vem, ao fim, a reafirmar aquilo que precisa ser negado, deslocando a atenção da eticidade (esfera central ao autor húngaro) para questões, em verdade, ligadas a um posicionamento essencialmente moral. O caráter prático do Direito, portanto, coloca-se ao passo que, "a moral é a ímpuissance mise en action" (MARX; ENGELS, 2003, p. 224), é a impotência posta em ato. O modo pelo qual há uma correlação íntima entre Direito e moral leva a isto: ao caráter impotente da moral, da justiça e do Direito natural. Segundo Lukács, depois de determinado grau de desenvolvimento da sociedade capitalista, longe de o complexo jurídico trazer um ímpeto revolucionário, ele, no limite, traz uma retórica moral e impotente:

Ao lado do Direito real, efetivamente funcionando, ao lado do assim chamado Direito positivo, sempre esteve presente na consciência social dos homens a ideia de um Direito não posto, que não brota de atos sociais, considerado como ideal para o primeiro, a saber, o Direito natural. Esse dever possui uma importância social extremamente diferenciada em diversos períodos: de uma grande influência conservadora (Direito natural católico na Idade Média), de uma força explosiva revolucionária (Revolução Francesa), a tensão se reduz muitas vezes a desejos piedosos retórico-professorais perante o Direito vigente." (LUKÁCS, 2013, p. 232)

Justamente o momento do que Lukács chamou de decadência ideológica da burguesia (Cf. LUKÁCS, 2010 b) traz o liberalismo - e não a democracia revolucionária de tempos pretéritos, em que o Direito natural teve um papel, principalmente na revolução francesa, bastante revolucionário - e, segundo Lukács, a moral, também por meio do Direito, ganhando destaque: "a ideologia liberal tapa o abismo de classe da sociedade civil-burguesa através da política entendida de forma idealizada, através da moral abstrata, etc." (LUKÁCS, 2011, p. 176) Isto se dá em meio ao próprio Direito, que deixa de trazer consigo o questionamento à ordem feudal por meio de uma "regulação jurídica universal" (LUKÁCS, 2013, p. 235) ${ }^{20}$ contraposta ao privilégio e começa a trazer junto de si um ímpeto essencialmente manipulatório, que marca o positivismo e que supõe a ordem do capital como uma segunda natureza inquestionável e eterna. Veja-se Lukács sobre isso:

O funcionamento do Direito positivo está baseado, portanto, no seguinte método: manipular um turbilhão de contradições de tal maneira que disso surja não só um sistema unitário, mas um sistema capaz de regular na prática o acontecer social contraditório, tendendo para a sua otimização, capaz de mover-se elasticamente entre polos antinômicos por exemplo, entre a pura força e a persuasão que chega às raias da moralidade -, visando implementar, no curso das constantes variações do equilíbrio dentre de uma dominação de classe que se modifica de modo lento ou acelerado, as decisões em cada caso mais favoráveis a essa sociedade, que exerçam as influências mais favoráveis a práxis social. Fica claro que, para isso, faz-se necessária uma técnica de manipulação bem própria, o que já basta para

\footnotetext{
${ }^{20}$ Veja-se o que diz Lukács sobre o assunto: "o fato de que, por exemplo, na Idade Média, o poder estatal fosse descentralizado, de que indivíduos pudessem dispor não só de armas, mas também de séquitos maiores ou menores de homens armados, fazia com que, naqueles tempos, a imposição de um decreto emanado do Direito estatal muitas vezes se tornasse uma questão de combate aberto entre o poder central e a resistência contra ele. A socialização da sociedade impôs nesse ponto formas de transição tão paradoxais, que para certas épocas o conteúdo do Direito passa a ser avaliar em que casos tais resistências são juridicamente válidas esmiuçar as contradições dessas teorias; elas decorrem principalmente da problemática da passagem contraditória do feudalismo para o capitalismo, que necessariamente procurou. Aqui não é o lugar para implementar uma regulação jurídica universal de todas as atividades sociais, como também simultaneamente transformou em questão principal da vida social a superioridade e, desse modo, a autoridade da regulação central perante todas as demais." (LUKÁCS, 2013, p. 235)
} 
explicar o fato de que esse complexo só é capaz de se reproduzir se a sociedade renovar constantemente a produção de "especialistas" (de juízes e advogados até policiais e carrascos) necessários para tal. Porém, a tarefa social vai ainda mais longe. (LUKÁCS, 2013, p. 247)

Segundo Lukács, não há uma contraposição real e efetiva entre aquilo que o Direito natural critica e o que vem a pressupor como sua base real. Em verdade, o modo pelo qual opera o Direito positivo conjuga, por meio da noção de justiça, um apelo moral e a manipulação pungente. Com a justiça e o Direito natural, tem-se segundo Lukács - ainda supostos justamente os especialistas - e a divisão do trabalho estranhada que eles supõem (Cf. SARTORI, 2010 a) - de tal modo que o sistema unitário colocado no Direito positivo não pode ser superado por meio de um outro sistema de dever social pensado em oposição a ele. Antes, é necessário, aquilo que acima foi chamado por Lukács de "um estágio da generidade mais elevado do que o realizável no direito positivo" e este estágio não poderia ser conseguido por meio de um apelo à justiça ou ao jusnaturalismo; antes, tratar-se-ia de sair das raias da moralidade e rumar ao questionamento da eticidade mesma por meio da questão do "que fazer? ". Se os questionamentos que daí - da moral, da justiça e do Direito natural - emergem podem trazer uma denúncia (a princípio, correta) do real e efetivo funcionamento do Direito positivo, seria preciso um questionamento que confluísse com uma consciência crítica que conseguisse superar (aufheben) o âmbito da esfera da moralidade.

Se, para Lukács, "os problemas ontológicos não possuem apenas um caráter puramente teórico, ainda que, naturalmente, a correção teórica seja decisiva para sua extensão à prática, à ética" (LUKÁCS, 2012, p. 104), percebe-se que a tematização da ética no autor traz consigo o modo pelo qual uma espécie de consciência crítica vem a questionar conscientemente a sociabilidade do momento presente, calcada na especificidade da generidade em-si. Mesmo que se possa partir de questões que aparecem, em um primeiro momento, por meio da moral, da justiça ou do Direito natural, a especificidade da ética leva estas questões a um patamar mais concreto ao trazer a centralidade da efetividade, e não do dever-ser - "nenhuma ética sem ontologia" (LUKÁCS, 2015, p. 181) ${ }^{21}$ - em que a compreensão da tessitura da realidade se correlaciona com a necessidade de atuação diante da mesma: para o autor, como dito, "os problemas ontológicos não possuem apenas um caráter puramente teórico", de tal maneira que a correção teórica tenha como critério a práxis concreta, tendo-se, por meio da correlação entre possibilidades concretas, o modo pelo qual o por teleológico e o dever a ele subordinado na atividade tenham o que chamou acima de "sua extensão à prática, à ética". Se, como apontaram Marx e Engels em uma passagem citada acima, "a moral é a impotência colocada em ato”, a esfera da ética é aquela em que, por meio da análise da tessitura da

\footnotetext{
${ }^{21}$ Sobre este ponto, José Paulo Netto aponta: "ao avançar para a construção da sua Ética, Lukács foi levado a reconhecer que haveria de fundá-la expressamente - pretendendo uma formulação histórico-sistemática efetivamente materialista e dialética, rigorosamente fiel à inspiração de Marx - na especificidade do ser social. Havia, portanto, de estabelecer, em primeiro lugar, a determinação histórico-concreta do modo de ser e de reproduzir-se do ser social. Vale dizer: sem uma teoria do ser (uma ontologia) social, a ética seria insustentável (enquanto uma ética materialista e dialética).” (NETTO, 2012, p. 16)
} 
própria realidade, tem-se a teorização acerca da complexa correlação entre possibilidades e a realidade efetiva. Por isso, em Lukács, uma crítica ao Direito se liga ao desenvolvimento de uma Ética, que traga uma análise imanente da atividade humana.

É justamente esta questão - a compreensão da complexa tessitura da realidade efetiva e das possibilidades que emergem disso - que, segundo o autor húngaro, é deixada de lado na teorização sobre a justiça e sobre o Direito natural, de tal modo que o potencial destas esferas, segundo Lukács, na melhor das hipóteses, está na possibilidade de, juntamente com o Direito, elas poderem ser criticadas ao se ter em conta a limitação do posto central do dever-ser em meio à problematização jurídica e moral (e também sobre a justiça). Trata-se, em verdade, da necessidade de uma crítica à sociedade capitalista que incorpore uma crítica ao Direito. (Cf. SARTORI, 2010 a). Trata-se também da necessidade da crítica implacável do que Lukács chamou em uma passagem acima citada "de todas as concepções jurídicas de igualdade e justiça. " Por meio destas últimas, a generidade em-si seria mantida enquanto uma espécie de condição humana imutável e, deste modo, justamente aquilo que precisa ser questionado - segundo o autor, em uma Ética - é tomado como suposto e, ao fim, justamente a impotência aparece como medida da atividade do homem que é permeada pela noção de justiça e pelo Direito. (Cf. SARTORI, 2015 b) Se é verdade que, para que se mencione parte de uma passagem trazida acima, "a justiça que emerge daí consta, por sua vez, no rol dos conceitos mais ambíguos no desenvolvimento humano", igualmente verdadeiro é que - no grau de desenvolvimento social em que o capitalismo não é mais essencialmente revolucionário ao, com o Direito, romper com os privilégios - ela está determinada pela estrutura manipulatória do Direito, em que, por meio da oscilação entre distintas antinomias (como trazido acima, trata-se da "pura força e a persuasão que chega às raias da moralidade", por exemplo) tem-se a manutenção do domínio classista burguês e, com ele, o ater-se à especificidade da generidade em-si.

Em meio ao intercâmbio de mercadorias e ao modo específico pelo qual se coloca o trabalho abstrato (e, com ele, o valor), para o autor da Ontologia, a noção de justiça opõe-se e se reconcilia com o Direito positivo ao mesmo tempo. Esta peculiar tensão coloca-se, segundo Lukács, somente na medida em que, como mencionado acima, "ela assume a tarefa, para ela insolúvel, de harmonizar idealmente ou até institucionalmente a diversidade e peculiaridade individual dos homens com o julgamento dos seus atos com base na igualdade produzida pela dialética do próprio processo da vida social. " Este processo é aquele em que, em meio à expansão da relaçãocapital, tem-se que as formas de regulamentação social, os sistemas de dever social, assim, "se tornavam componentes dirigidos pelo domínio material-universal do capital. " (LUKÁCS, 2010 a, p. 283) E, portanto, o modo pelo qual se coloca a mediação do Direito sempre tem estas determinações como supostas e efetivas, de tal modo que, segundo Lukács, tem-se, em qualquer concepção crítica acerca da efetividade da sociedade civilburguesa, necessidade de uma crítica ao Direito. 
Ou seja, por mais que se tenha, no próprio Direito, com uma tensão frente ao Direito positivo e ao modo pelo qual se conforma a generidade em-si, real e efetivamente, tem-se uma reconciliação entre a justiça, o Direito natural e a generidade em-si. Deste modo, de acordo com a Ontologia, tal tensão só poderia ser aproveitada se remetesse para além do terreno do Direito e buscasse a supressão do atual estado da generidade. No que, também por este ângulo, nota-se a importância da tematização da ética em Lukács. Seria justamente ela que colocaria questões decisivas - relacionadas às mediações entre a teoria e a práxis, entre a compreensão da real tessitura da efetividade e sua transformação concreta - e que poderiam trazer à tona o modo concreto pelo qual se põe o tema decisivo diante das vicissitudes da sociedade capitalista, aquele do "que fazer?". Tanto é assim que, diante da crítica heideggeriana ao presente (Cf. SARTORI, 2012, 2016 d), Lukács diz: "o contraste, tão importante para a influência exercida por Heidegger, entre autenticidade e inautenticidade do ser humano num mundo manipulado por 'o impessoal [das Man]' é, no fundo, uma questão ética que, também no caso dele, como veremos mais adiante, necessariamente terminará numa das alternativas oferecidas pela pergunta 'que fazer?'." (LUKÁCS, 2012, p. 91) A questão ética central, portanto, é esta: "que fazer? ”. Se Lukács adotou uma postura, até certo ponto, unilateral sobre a questão em História e consciência de classe (Cf. LUKÁCS, 2003), hipertrofiando o papel da prática, o mesmo não se dá em sua obra madura, a qual vê a questão de modo meandrado e nuançado, tendo em conta o cuidado devido com a apreensão da efetividade e, com isto, trazendo à tona a tematização da eticidade, e não o posto central do dever-ser.

\section{A QUESTÃO DA ÉtICA E A SUPERAÇÃO DA GENERIDADE EM-SI E DO STALINISMO}

Portanto, ao traçar a inseparabilidade entre Direito, intercâmbio mercantil e a lei do valor, Lukács procura explicitar as determinações materiais que permeiam o Direito e, simultaneamente, trazer à tona o modo pelo qual algumas tensões peculiares aparecem no seio deste complexo social mesmo. Com isso, o autor pretende apreender o ser-propriamente-assim deste complexo social com o cuidado devido. Neste último tem-se, até certo ponto, um protesto contra o mundo existente (busca-se, com referência à justiça ao Direito natural, um estágio da generidade mais elevado do que o realizável no direito positivo) ao mesmo tempo em que este protesto tende a se colocar no terreno do Direito e da moral, de modo a tornar-se impotente ao tomar como suposta a conformação daquilo mesmo contra o qual, de certo modo, volta-se. A crítica do autor da Ontologia ao Direito, à justiça e ao Direito natural é decidida. Porém, também vem a considerar que, em meio ao complexo jurídico mesmo, emergem questões importantes as quais, com as lentes jurídicas, não podem ser resolvidas, mas por vezes, poderiam levar a uma crítica ao Direito. Deste modo, o central deixa de ser o posto central do dever-ser e vem a se apresentar como referência a uma questão decisiva: "que fazer? ". Neste sentido, a relação entre a esfera ética e a 
práxis transformadora aparece de modo bastante claro, tendo-se isto por central na obra madura de Lukács:

Minha atividade essencial depois de 1956 está ligada a estas tarefas. As obras maiores, uma recém-concluída Ontologie des gesellschaftlichen Seins (Ontologia do ser social) e uma projetada Ética pretendem oferecer contribuições para a fundamentação de uma práxis comunista no presente ... e no futuro. (LUKÁCS, 2008, p. 212)

Novamente, o autor coloca como ponto terminal de suas pesquisas acerca da ontologia a ética. A questão, inclusive, aparece ao passo que justamente esta pesquisa poderia, para que se use as palavras citadas acima, "oferecer contribuições para a fundamentação de uma prática comunista no presente...e no futuro". Por mais que questões importantes possam aparecer nos meandros das tensões que permeiam o Direito, a posição de Lukács é clara: a partir destas tensões encontra-se somente uma possibilidade efetivamente crítica, o questionamento radical do Direito, da moral, da justiça e do Direito natural.

Ou seja, em meio a uma crítica ao Direito e ao modo pelo qual as tensões sociais aparecem nestas esferas, a questão da transformação concreta da realidade efetiva aparece a Lukács como decisiva, e não o posto central do dever-ser; se o dever é certamente um elo mediador na atividade humana (Cf. LUKÁCS, 2013; FORTES, 2016), ele não é de modo algum o momento preponderante na práxis social ${ }^{22}$, de tal modo que seu caráter de mediação em meio à totalidade social faz com que a conformação real e efetiva da tessitura da sociedade - para que se use os termos deste escrito, a eticidade - venha a ganhar destaque nos apontamentos lukacsianos. (Cf. ANDRADE, 2016; SARTORI, 2010 a) O campo da ética é aquele em que a atividade humana é vista diante da historicidade e objetividade do ser social, que, enquanto complexo de complexos, traz possibilidades e potencialidades distintas (mais ou menos limitadas) em cada complexo parcial. Em sua Ontologia, Lukács procura deixar claras as limitações da moral e do Direito, deixando claro que, na melhor das hipóteses, elas poderiam trazer à consciência dos homens questões que, no limite, poderiam levar ao questionamento substantivo da sociabilidade presente, e, com ela, do Direito, da moral e mesmo da política (entendida enquanto campo estatal) (Cf. SARTORI, 2015 b); trata-se do processo que, objetivamente, liga-se à transformação da tessitura da sociedade e, com isso, da própria eticidade. Neste ponto, diz o autor húngaro: "ética em desenvolvimento a) Impassível rejeição (por vezes mero mal-estar) contra costumes, Direito, moral e política." (LUKÁCS, 2015, p. 205) A questão do “que fazer?” leva a o autor da Ontologia a considerar, no limite, a própria necessidade de fenecimento do Direito e da moral: "o domínio da ética pelo fenecimento do Direito e da Moral." (LUKÁCS, 2015, p. 69) Trata-se da já mencionada crítica ao posto central do dever-ser, de tal feita que não se trataria de elaborar, de modo mais ou menos cerebrino, um outro sistema de dever, mas de enfocar a relação entre subjetividade e objetividade no processo que poderia

\footnotetext{
${ }^{22}$ Como aponta Lukács, também remetendo à questão da ética: "em sua essência mais íntima, todo o âmbito da atividade do ser humano é determinado pela realidade existente em si, ou seja, pelo seu espelhamento na consciência predominante em cada época: essas concepções atuam sobre os diversos conteúdos e formas da práxis humana. Esse complexo só pode receber um tratamento adequado e aprofundado no âmbito das ciências sociais concretas, nas análises concretas da práxis humana, incluída a ética." (LUKÁCS, 2012, p. 74-75)
} 
levar, no limite, à supressão da generidade em-si e à emergência da generidade para-si. Ou seja, trata-se de apreender - também por meio da moral e do Direito, mas remetendo para além delas - questões essenciais à conformação da sociabilidade do presente de modo a levar tais questões ao patamar em que podem ser resolvidas, aquele da práxis.

Isto seria decisivo. Ao fim, traria temáticas que levam ao questionamento radical do próprio "socialismo" do século XX, que teve bastante influência stalinista (Cf. CLAUDIN, 2013) e que levou a uma práxis social eivada pelo estranhamento e pela reprodução da generidade em-si (Cf. SARTORI, 2016 b); no que diz Lukács: "período stalinista: em vez do desenvolvimento avante da moral (e Direito) para a ética, reconversão da moral em Direito." (LUKÁCS, 2015, p. 173) A crítica lukacsiana à moral, pois, não é só uma crítica ao liberalismo; com ela, o autor destaca a necessidade de uma tematização séria acerca do fenecimento do Direito e da impotência do stalinismo diante desta questão importante e bastante complexa. Assim, não se poderia, de modo algum, pensar o socialismo como uma questão moral, até mesmo porque se teria a reconversão da moral em Direito como algo a ser questionado de maneira decidida - o fundamento verdadeiro destes dois, e para a extinção destes dois, seria justamente uma ética em desenvolvimento, construída justamente em meio à transformação concreta das condições de vida dos homens.

Deste modo, percebe-se: a partir das tensões que aparecem em meio ao Direito seria possível, no limite, buscar, para que se use a dicção mencionada acima, um "desenvolvimento avante da moral (e Direito) para a ética”; isto seria essencial para que se pudesse compreender não só a especificidade do complexo jurídico, mas para que a contraditoriedade do ser social do capitalismo pudesse ser apreendida em sua real e efetiva conformação. No que ainda diz o autor sobre o assunto: "Direito - Moral - Ética Nova (puro humano) posição do indivíduo para com o gênero" (LUKÁCS, 2015, p. 173), de tal modo que há certa escalada das questões jurídicas rumo à questão do "que fazer?": se "pode-se dizer que a ética constitui nas práticas humanas um centro mediador entre o Direito puramente objetivo e a moralidade puramente subjetiva" (LUKÁCS, 1966, p. 220), há de se perceber que as "práticas humanas" a que se refere Lukács trazem consigo diferentes possibilidades de acordo com o complexo social a que se ligam de modo mais forte. Neste sentido, o que propõe o marxista húngaro é uma crítica decidida à esfera moral e à esfera jurídica, por mais que, até certo ponto, de modo bastante mediado, fosse possível ter como ponto de partida as tensões que daí emergem para uma superação do próprio terreno do Direito; seria possível romper com o posto central do dever-ser e, ao apreender a real tessitura da sociabilidade burguesa, transformá-la no sentido revolucionário.

Isto implicaria, inclusive, no destaque a ser dado na relação entre indivíduo e gênero. Se este desenvolvimento é antagônico em meio à generidade em-si, na generidade para-si, ele aparece de tal modo que "no lugar da sociedade civil-burguesa antiga, com suas classes e antagonismos de classe, teremos uma associação 
na qual o desenvolvimento livre de cada um é a condição para o desenvolvimento livre de todos." (MARX; ENGELS, 1998, p. 45) Também em Marx, nota-se, a questão do socialismo é aquela e que há uma relação entre indivíduo e gênero ("todos") distinta. (Cf. VAISMAN, 2007) A questão não é nada simples, porém. Tanto é assim que ela apareceu desfigurada em meio ao desenvolvimento da própria revolução russa, que Lukács, mesmo que de modo meandrado, apoiou durante a vida toda. (Cf. SARTORI, 2016 b) No que toca o Direito e a moral, o autor é claro: "stalinismo reconversão da moral em Direito. Paralisia. Dificuldade do pôr a questão ética" (LUKÁCS, 2015, p. 175) Justamente contra tal paralisia, por meio da tematização de diversas questões, dentre elas, aquela relativa à relação entre o indivíduo e a generidade, o autor desenvolve sua Ontologia, que culminaria em uma Ética, que procura, como mencionado, "a fundamentação de uma práxis comunista no presente ... e no futuro." Neste sentido, pode-se dizer que a questão ética se coloca justamente a partir de uma crítica ao Direito e à especificidade da generidade em-si, como visto, para o autor, correlacionados e indissociáveis. No que diz Lukács:

Por mais diferenciados que sejam os conteúdos jurídicos em sua gênese e em sua validade, também a forma jurídica desenvolverá tal similaridade só no decurso da história; e isso de modo tanto mais forte e puro quanto mais puramente social foi se tornando a vida social. É possível perceber, já nessa mesma forma, justamente quando a examinamos de modo puramente formal, uma autêntica contraditoriedade: por um lado, essa forma é rigorosamente geral, já que sob a mesma categoria sempre são subsumidos de uma só vez e uniformemente todos os casos que podem ser associados a dado imperativo social. $\mathrm{O}$ fato de, em muitos casos, ser preciso adicionar corretivos diferenciadores não muda nada na essência dessa estrutura, porque as subdivisões, as coordenações, os aditivos definidores etc. possuem igualmente a mesma constituição - que subsume tudo sob um item geral. Por outro lado, surge concomitantemente com essa tendência para a validade universal uma notável - e igualmente contraditória - indiferença diante da razão pela qual os homens singulares, cujos pores teleológicos uma prescrição jurídica desde sempre é chamada a influenciar, obedecem ao imperativo aqui estatuído (problema da legalidade). O imperativo, por seu turno, via de regra é puramente negativo: certas ações não devem ser consumadas; se de fato se efetua a abstinência de tais ações, seus motivos interiores, tanto quanto os exteriores, são totalmente indiferentes. A consequência disso é que a correção legal pode estar associada com uma extrema hipocrisia. Os comportamentos, conflitos etc. múltiplos e extremamente distintos entre si que daí decorrem, e que podem se tornar muito importantes para a compreensão de moral e ética, só poderão ser tratados de modo adequado na Ética. (LUKÁCS, 2013, p. 234)

É bastante importante apontar que, em meio ao tema que aqui tratamos, Lukács traz também ponderações sobre a forma jurídica. O assunto, é importante que se diga, é central para a crítica marxista ao Direito e foi tratado, sobretudo, por Pachukanis. (Cf. NAVES, 2000 a; KASHIURA, 2009) O marxista húngaro, neste ponto, não deixa de trazer a tona o fato segundo o qual a dimensão homogeneizadora do complexo jurídico - que traz o aspecto central da forma jurídica, segundo Lukács - só aparece no decurso da história e, mais propriamente, somente na sociedade em que o afastamento das barreiras naturais alcança uma dimensão global, a sociedade capitalista. (Cf. SARTORI, 2017). Esta última, como vimos, traz consigo o fato segundo o qual, pela primeira vez na história, os sistemas de dever social, em sua dimensão real e efetiva, para que se use as palavras citadas acima neste texto, "se tornavam componentes dirigidos pelo domínio material-universal do capital." Ou seja, a dimensão 
universal do capitalismo e a dimensão universal do Direito são correlatas, tratando-se de algo amparado em uma forma específica de mediação estranhada, que apresenta o seu caráter, como já mencionado, "tanto mais forte e puro quanto mais puramente social foi se tornando a vida social”; neste sentido, sob o modo de produção capitalista, aparece uma universalidade - vista pelas lentes jurídicas como uma espécie de segunda natureza - que, tal qual apontam Althusser e seus seguidores, precisa, caso se adote uma posição marxista, ser suprimida. Qualquer "humanismo" que surja tomando esta base (aquela da generidade em-si) como substrato é, tal qual o Direito, essencialmente manipulatório e, no limite, para que se use a diç̧ão de Lukács, depois de determinado momento, hipócrita. A forma jurídica apresenta-se, pois, como homogeneizadora e vem justamente a trazer uma forma de universalidade que oculta os antagonismos sociais que determinam a especificidade do modo de produção capitalista.

A ausência de contraditoriedade que aparece na forma jurídica, segundo Lukács, tem como base real as contradições da sociedade civil-burguesa e se coloca enquanto o duplo caráter do reflexo jurídico (Cf. SARTORI, 2010 a) se põe justamente ao tentar apreender precisamente a realidade social a partir do elemento jurídico; o serpropriamente-assim da sociedade escapa ao jurista na medida mesma em que este se esforça em apreendê-lo. A forma universal do Direito é rigorosamente geral e, nesta medida mesma, deixa de lado a essência antagônica do ser social do capitalismo, tal qual o "humanismo" criticado pelo althusserianismo. No entanto, este não é, para o autor da Ontologia, a única forma de universalidade colocada como possibilidade no ser social; como vimos acima, esta universalidade se coloca com a generidade em-si ao passo que Lukács defende que se trata de superar esta forma de generidade noutra, que suprima o próprio domínio material-universal do capital, na generidade para-si, conformada no socialismo.

Se seguirmos Lukács, pode-se dizer que a forma jurídica se impõe de modo geral ao passo que traz consigo a subsunção que de uma só vez e uniformemente coloca um imperativo social, para que se use a dicção de Marx, de acordo com "um igual padrão de medida". (Cf. MARX, 2012, p. 31) 23 Justamente este aspecto homogeneizador do Direito, de acordo com Lukács, é bastante manipulatório já que, por vezes, para que se use o que diz o autor acima, "em muitos casos, ser preciso adicionar corretivos diferenciadores" igualmente marcados pela estrutura da subsunção. (Cf. SARTORI, 2010 a) Ou seja, a forma jurídica traz consigo uma medida - ligada à sociedade civil-burguesa e, portanto, também ao intercâmbio de mercadorias submetido ao capital - que, oscilando entre polos igualmente unilaterais (entre a pura força e a persuasão que se aproxima da moralidade, por exemplo), e, sempre de maneira seletiva - com corretivos diferenciadores - afirma o domínio material-universal do

\footnotetext{
${ }^{23}$ Segundo Marx, "Direito, por sua natureza, só pode consistir na aplicação de um padrão igual de medida; mas os indivíduos desiguais (e eles não seriam indivíduos diferentes se não fossem desiguais) só podem ser medidos segundo um padrão igual de medida quando observados do mesmo ponto de vista, quando tomados apenas por um aspecto [...] todos os outros aspectos são desconsiderados." (MARX, 2012.p. 31)
} 
capital e, portanto, também mediante a moral, o Direito natural e a noção de justiça, reafirma como horizonte da humanidade a generidade em-si, que se conforma de modo decisivo na sociedade capitalista. Portanto, para Lukács, a questão, como levantado acima, não poderia ser resolvida juridicamente, mas com referência à questão do "que fazer?", questão que, essencialmente, seria aquela de sua Ética.

A validade universal do Direito - contraposta, na passagem ao capitalismo, ao privilégio -, neste sentido, traz, inclusive, uma tensão com a moralidade e com o ímpeto de justiça. No entanto, é preciso se atentar ao fato de não ser isso o decisivo, segundo Lukács. Com imperativos, sobretudo, negativos, poderia haver extrema hipocrisia por vezes, já que, na estrutura mesma do Direito também se tem a situação em que os indivíduos se colocam como sujeitos e, nesta mesma medida, como mencionado acima, "seus motivos interiores, tanto quanto os exteriores, são totalmente indiferentes. " ${ }^{24}$ Segundo o autor da Ontologia, no Direito mesmo convivem tendências, até certo ponto, opostas, mas que convergem na manutenção do domínio material-universal do capital, este último o qual dá amparo à generidade em-si; isso se dá, segundo Lukács, ao passo que seria possível que, em meio às tensões que aparecem no terreno do Direito, se remetesse - por meio de uma compreensão sensata da realidade social, que poderia ser fornecida pelo marxismo - a uma crítica ao próprio complexo jurídico; procurar por um estágio da generidade mais elevado do que o realizável no Direito positivo pode, assim, ser um sintoma de que determinada formação social é anacrônica. Ao mesmo tempo, o modo imediato pelo qual este protesto e este descontentamento aparecem - por meio da noção de justiça e pelo Direito natural - não poderia ser mais equivocado quando se trata de buscar uma crítica real e efetiva ao estágio de generidade presente.

Lukács, assim, aponta que, por meio das tensões que se apresentam na esfera jurídica, é possível certa tomada de consciência acerca das vicissitudes do presente, e do próprio funcionamento do Direito positivo; no entanto, tratar-se-ia, essencialmente, de uma tomada de consciência, que, diga-se de passagem, não necessariamente seria crítica já que tanto a noção de justiça quanto o Direito natural permanecem no terreno do Direito e, deste modo, tornam a generidade em-si uma espécie de segunda natureza. A tematização sobre a generidade, pois, seria de grande relevo para que ficassem claros os meandros pelos quais passa um posicionamento crítico que pudesse trazer uma transformação social real e efetiva; pode parecer um contrassenso, mas, em verdade, segundo Lukács, tratar dessa questão é levantar questões essenciais para uma Ética.

\section{CONSIDERAÇÕES FINAIS: ACERCA DE UMA ÉTICA EM DIREÇÃO A SUPRESSÃO DO CAPITALISMO}

Neste pequeno texto averiguamos como que a questão da ética aparece em Lukács de modo a opor-se

\footnotetext{
${ }^{24}$ A tematização acerca do "sujeito de direito" não é central para Lukács, embora o autor apreenda diversas questões que estão intimamente correlacionadas ao tema. Sobre a questão, Cf. SARTORI, 2017.
} 
ao posto central do dever-ser, trazendo consigo uma crítica decidida ao Direito o qual, segundo o autor húngaro, mesmo que com tensões constitutivas do ser do complexo jurídico, permanece, sempre, ao fim, tomando como suposto o atual grau de desenvolvimento social, aquele da generidade em-si. Ou seja, a defesa lukacsiana da teorização acerca da eticidade perpassa a compreensão dos meandros da atividade do homem e do Direito na medida em que seria possível, a partir do modo pelo qual as questões sociais aparecem no terreno do Direito, remeter, por meio do uma crítica decidida ao complexo jurídico, e com auxílio do marxismo, para além da moral, do Direito natural e do Direito positivo. Tratar-se-ia, em verdade, de trazer a questão decisiva para aqueles que pretendem um posicionamento efetivamente crítico acerca da sociedade existente, aquela do "que fazer?". Se seguirmos Lukács, podemos dizer que o universalismo e o "humanismo" que aparecem no Direito, assim, são aqueles que efetivamente devem ser criticados (tal qual destacado por grande parte da crítica marxista ao Direito no Brasil), já que amparados na pré-história do gênero humano, na história do estranhamento do homem; no entanto, ao mesmo tempo, segundo Lukács, a generidade em-si fornece também algo mais: as bases para que seja pensável uma supressão da própria sociabilidade do capital, de tal feita que a tematização da ética no autor da Ontologia é aquela que diz respeito, não tanto à tensão entre justiça, Direito positivo e Direito natural, mas à passagem das possibilidades trazidas (e caladas) pela sociedade capitalista e a efetivação dessas possibilidades com a supressão do capital, do Direito e da moralidade marcada pela subjetividade burguesa; para isso, de acordo com o autor da Ontologia, seria extremamente necessário um passo no sentido da crítica decidida ao posto central do dever-ser, e esse passo passaria pela Ética e, com ela, pela questão do "que fazer?", no século XX, colocada de modo exemplar por Lenin e essencial na crítica à sociedade capitalista.

\title{
LAW, ETHICS AND SPECIES IN GYÖRGY LUKÁCS' LATE WORK: ON TENSIONS IN THE JURIDICAL SPHERE
}

\begin{abstract}
Having in mind the lukacsian critic to the "centrality of the ought", we intend to analyze the matter of ethics on Lukács' late work - Ontology and Esthetics - having as a departing point the critic of Law and its universality, which, according to the Hungarian Marxist appears as the universality of capitalist society in what he calls "Species in-itself". We intend to analyze the tensions that are inherent to the juridical sphere, trying to explain its structure. As a conclusion, we intent to make clear that the lukacsian ethic is, at certain level, a result of his critic of Law.
\end{abstract}

Keywords: Lukács; Law; Ethics, Capitalism. 


\section{BIBLIOGRAFIA}

ALCÂNTARA, Norma. Ontologia e alienação. São Paulo, Instituto Lukács, 2014.

ALTHUSSER, Louis. A favor de Marx Tradução por Dirceu Lindoso. São Paulo: Zahar, 1979. A querela sobre o humanismo (I). In: Crítica Marxista. No 9. São Paulo: Xamã, 1999. A querela sobre o humanismo (II). In: Crítica Marxista. No 12. Rio de Janeiro, 2002.

ANDRADE, Mariana. Ontologia, dever e valor em Lukács. Maceió: Coletivo Veredas, 2016.

DWORKIN, Ronald. A justiça de toga. Tradução por Jefferson Luis Camargo. São Paulo. Martins Fontes, 2010. Levando os direitos a sério. Tradução por Nelson Boeira. São Paulo: Martins Fontes, 2007. O império do Direito. Tradução por Jefferson Luiz Camargo. São Paulo: Martins Fontes, 2014 Uma questão de princípios. Tradução por Luis Carlos Borges. São Paulo: Martins Fontes, 2005. Levando os direitos a sério. São Paulo: Martins Fontes, 2007.

ENGELS, Friedrich; KAUTSKY, Karl. O socialismo jurídico. Tradução por Márcio Naves e Lívia Cotrim. São Paulo: Boitempo, 2012.

FORTES, Ronaldo Vielmi. As três determinações fundamentais da análise lukacsiana do trabalho: modelo das formas superiores, prioridade ontológica e abstração isoladora Crítica da ideia da centralidade do trabalho em Lukács. In: Revista On Line de Filosofia e Ciências Humanas, No 22. Belo Horizonte: 2016. (Disponível em www.verinotio.org)

Las categorias de la objetivación (Vegegenständlichung), enajenación (Entäusserung) y alienación (Entfremdung) em el último Lukács. Tradução por Julián Fava. In: La alienación: historia y actualidad. Buenos Aires: Herramienta, 2012.

HART, Herbert L. A. O conceito de Direito. Tradução por A. Ribeiro Mendes. Lisboa: Fundação Calouste Gulbenkian, 2003.

KELSEN, Hans. Teoria pura do Direito. Tradução por João Baptista Machado. Martins Fontes: São Paulo, 2003.

HELLER, Agnes. Cotidiano e História. Tradução por Carlos Nelson Coutinho e Leandro Konder. Rio de Janeiro, 1972.

KASHIURA JR, Celso Naoto. Crítica da igualdade jurídica. São Paulo: Quartier Latin, 2009. Sujeito de direito e capitalismo. São Paulo: Expressão Popular, 2014

LUKÁCS, György. Conversando com Lukács. Traduzido por Giseh Vianna Konder. Rio de Janeiro: Paz e Terra, 1969.

Escritos de Moscu: estúdios sobre literatura y politica. Tradução por Martín Koval e Miguel Vedda. Buenos Aires, Gorla, 2011.

Estética, La Peculiaridad de lo Estético. Tradução por Manuel Sacristan. V. III - Questiones Preliminares y de Princípio. México: Ediciones Grijalbo, 1966.

L' Estraniazone, Ontologia Dell'Essere Sociale II. Riuniti. Roma. 1981 - Disponível em: <http://www.sergiolessa.com>. Acesso em: 24 fev. 2008. Trad. Maria Norma Alcântara Brandão de Holanda e Sergio Lessa.

Marxismo e teoria da literatura. Tradução por Carlos Nelson Coutinho. São Paulo: Expressão Popular, 
$2010 \mathrm{~b}$.

Notas para uma ética. Tradução por Sérgio Lessa. Alagoas: Instituto Lukács, 2015.

O jovem Marx e outros escritos filosóficos. Tradução por Carlos Nelson Coutinho e José Paulo Netto.

Rio de Janeiro, UFRJ, 2007.

Pósfácio de 1967. In: História e consciência de classe. Tradução por Rodnei Nascimento. São Paulo: Martins Fontes, 2003.

$2010 \mathrm{a}$

Prolegômenos para uma ontologia do ser social. Tradução por Nélio Schneider. São Paulo: Boitempo,

Para uma ontologia do ser social I. Tradução por Carlos Nelson Coutinho, Mario Duayer e Nélio Schneider. São Paulo: Boitempo, 2012

Para uma ontologia do ser social II. Tradução por Nélio Schneider. São Paulo: Boitempo, 2013

Socialismo e Democratização. Tradução por Carlos Nelson Coutinho e José Paulo Netto. Rio de Janeiro:

UFRJ, 2008.

MARX, Karl. Contribuição à Crítica da Economia Política. Tradução Florestan Fernandes. São Paulo: Expressão Popular, 2009.

Crítica ao programa de Gotha. Tradução por Rubens Enderle. São Paulo: Boitempo, 2012

O Capital. Tradução por Rubens Enderle. São Paulo: Boitempo, 2013.

O Capital, Volume I. Tradução por Regis Barbosa e Flávio R. Kothe São Paulo: Nova Cultural, 1988.

O Capital, Volume II. Tradução por Regis Barbosa e Flávio R. Kothe São Paulo: Nova Cultural, 1987.

O Capital, Volume IV. Tradução por Regis Barbosa e Flávio R. Kothe São Paulo: Nova Cultural, 1986.

O Capital, Volume V. Tradução por Regis Barbosa e Flávio R. Kothe. São Paulo: Nova Cultural, 1985.

MARX, Karl; ENGELS, Friedrich. A sagrada família. Tradução por Marcelo Backers. São Paulo: Boitempo, 2003. Ideologia alemã. Tradução por Rubens Enderle. São Paulo: Boitempo, 2007.

O Manifesto Comunista. Tradução por Maria Lucia Como. Rio de Janeiro: Paz e Terra, 1998.

MÉSZÁROS, István. Para além do capital: rumo a uma teoria da transição. Tradução por Paulo Cezar Castanheda e Sérgio Lessa. São Paulo: Boitempo, 2002.

NAVES, Márcio Bilharinho. Marx: ciência e revolução. São Paulo: Moderna, 2000 a.

Marxismo e direito: um estudo sobre Pachukanis. Boitempo: São Paulo, 2000 b

A questão do direito em Marx. São Paulo: Expressão Popular, 2014.

NETTO, José Paulo. Apresentação. In: Para uma ontologia do ser social I. Tradução por Carlos Nelson Coutinho, Mario Duayer e Nélio Schneider. São Paulo: Boitempo, 2012.

PACHUKANIS, E.P. Teoria geral do direito e o marxismo. Tradução por Paulo Bessa. Rio de Janeiro: Renovar, 1988.

SARTORI, Vitor Bartoletti. A questão da crítica ao Direito à luz da obra madura de Lukács. In: TORRIGLIA, Patrícia Laura; MÜLLER, Ricardo Gaspar; LARA, Ricardo; ORTIGARA, Vidalcir (Org.). Ontologia e crítica do tempo presente. Florianópolis: Em debate, 2015 b.

A questão da universalidade do humanismo à luz da supressão do capital em Marx e Lukács. In: Revista textos e debates n. 23. Roraima: UFRR, 2013.

Apresentação. In: TERTULIAN, Nicolas. Lukács e seus contemporâneos. Tradução por Pedro Corgozinho. São Paulo: Perspectiva, 2016 d.

"Diálogos" entre Lukács e Pachukanis acerca da crítica ao Direito. In: Surgência: Revista de Direito e 
Movimentos Sociais, No 2. Brasília: UNB, Lumen Juris, 2017 (no prelo)

Hermenêutica filosófica e marxismo: sobre uma peculiar "ausência-presença". In: Revista Pensar: Fortaleza, 2016 c. (no prelo)

Lukács e a crítica ontológica ao Direito. São Paulo: Cortez, 2010 a

Lukács e a questão da técnica em Heidegger. Verinotio: Revista On Line de Educação e Ciências Humanas, $n^{\circ}$ 13. Belo Horizonte, 2012. (disponível em www.verinotio.org)

Lukács e as Figuras da Política na Sociedade Capitalista: Apontamentos sobre Democracia e Liberalismo. Prima Facie (v. 15; n. 28). João Pessoa: UFBP, 2016 a.

Lukács e Heidegger: a ontologia do século xx diante de Hegel. In: Anuário Lukács 2016 (Org. VEDDA, Miguel; COSTA, Gilmaísa; ALCANTARA, Norma). Maceió: Instituto Lukács, 2016 b.

Marx, marxismo e o terreno do Direito: um debate necessário. In:Verinotio: Revista On Line de Filosofia e Ciências Humanas, n 19. Belo Horizonte: 2015 c. (disponível em www.verinotio.org)

Moral, Ética E Direito: Lukács e a Teoria do Direito. Belo Horizonte: Sapere Auede, 2015 a.

O segundo Heidegger e Lukács: alienação, história e práxis. In:Verinotio: Revista On Line de Educação e Ciências Humanas, n 11. Belo Horizonte, 2010 b. (disponível em www.verinotio.org)

Teoria geral do direito e marxismo de Pachukanis como crítica marxista ao direito. In:Verinotio: Revista On Line de Filosofia e Ciências Humanas, n 19. Belo Horizonte: 2015 d. (disponível em www.verinotio.org)

STECK, Lênio. Hermenêutica jurídica e(m) crise. Porto Alegre: Livraria do advogado, 1999.

TERTULIAN, Nicolas. Aliénation et desaliénation: une confrontation Lukács-Heidegger. In: Actuel Marx n. 39. PUF: Paris, 2006.

Lukács: etapas de seu pensamento estético. Tradução por Renira Lisboa de Moura Lima. Ed. UNESP. São Paulo: 2008.

Lukács e o Stalinismo. Tradução Por Ronaldo Vielmi Fortes. In: Verinotio: 07 Revista On Line de Educação e Ciências Humanas, n 11 . Belo Horizonte: 2007 b (disponível em www.verinotio.org)

Lukács e seus contemporâneos. Tradução por Pedro Corgozinho. São Paulo: Perspectiva, 2016.

O pensamento do ultimo Lukács. Tradução por Juarez Duayer. Revista Outubro. No 16. São Paulo, 2007

a

Pósfácio. In: LUKÁCS, György. Prolegômenos para uma ontologia do ser social. Tradução por Nélio Schneider. São Paulo: Boitempo, 2010.

VAISMAN, Ester. As relações entre indivíduo e gênero: reflexões sobre os Prolegômenos para uma ontologia do ser social de G. Lukács. In: Novos Rumos v. 22. Marília: UNESP, 2007.

Marx e Lukács e o problema da individualidade: algumas aproximações. In: Perspectiva, v. 27, n.2. Florianópolis: UFSC, 2009.

Trabalho enviado em 07 de janeiro de 2017.

Aceito em 17 de abril de 2017. 